\title{
Novel Calcium Zirconate Silicate Cement Biomineralize and Seal Root Canals
}

\author{
Soram Oh ${ }^{1,+}{ }^{(D)}$, Sung-In Cho ${ }^{2,+}$, Hiran Perinpanayagam ${ }^{3}{ }^{(D)}$, Jinsu You ${ }^{4}$, Seong-Hyeon Hong ${ }^{4}$, \\ Yeon-Jee Yoo ${ }^{2}$, Seok Woo Chang ${ }^{1}$, Won-Jun Shon ${ }^{2}$, Jun-Sang Yoo ${ }^{5}$, Seung-Ho Baek ${ }^{2}$ \\ and Kee-Yeon Kum 2,* \\ 1 Department of Conservative Dentistry, Kyung Hee University Dental Hospital, \\ Kyung Hee University School of Dentistry, 23 Kyungheedae-ro, Dongdaemun-gu, Seoul 02447, Korea; \\ soram0123@gmail.com (S.O.); swc2007smc@gmail.com (S.W.C.) \\ 2 Department of Conservative Dentistry, Dental Research Institute, Seoul National University Dental \\ Hospital \& Seoul Dental Hospital for Disabled, Seoul National University School of Dentistry, \\ 101 Daehak-ro, Jongro-gu, Seoul 03080, Korea; gbpaul@naver.com (S.-I.C.); \\ dusw10808@hanmail.net (Y.-J.Y.); endoson@snu.ac.kr (W.-J.S.), shbaek@snu.ac.kr (S.-H.B.) \\ 3 Schulich School of Medicine \& Dentistry, University of Western Ontario, 1151 Richmond Street, \\ London, ON N6A3K7, Canada; hperinpa@uwo.ca \\ 4 Department of Materials Science and Engineering, Seoul National University, 1 Kwanak-ro, \\ Kwanak-gu, Seoul 08826, Korea; jsyou@snu.ac.kr (J.Y.); shhong@snu.ac.kr (S.-H.H.) \\ 5 U Dental Hospital, 175 Dasan-ro, Jung-gu, Seoul 04608, Korea; dryjskr@daum.net \\ * Correspondence: kum6139@snu.ac.kr; Tel.: +82-2-2072-2651; Fax: +82-2-2072-3859 \\ + The first two authors contributed equally to this work.
}

Received: 11 March 2018; Accepted: 10 April 2018; Published: 11 April 2018

\begin{abstract}
This study evaluated the sealing ability of gutta-percha (GP) with a calcium silicate-based sealer and a novel calcium zirconate containing calcium silicate cement (ZC). The root canals of the extracted premolars were prepared, which were then randomly allocated to three experimental groups (12 root canals per group) for obturation by continuous wave of condensation with the GP and AH 26 sealer (CW); obturation using a single GP with a calcium silicate-based EndoSequence BC sealer (SC); or obturation with ZC. The roots were inserted into sterile Eppendorf tubes, which were inoculated coronally with Porphyromonas gingivalis. The amount of endotoxin leakage into the apical reservoirs were measured using the Limulus Amebocyte Lysate (LAL) assay over 21 days, with comparisons made using one-way ANOVA and Scheffe's tests $(\alpha=0.05)$. After 21 days, $75 \%$ of the canals that had been obturated by SC, $50 \%$ of those obturated by CW and $42 \%$ of those obturated by ZC showed endotoxin leakage. The amount of leakage was higher in the SC canals than in the CW $(p=0.031)$ or ZC $(p=0.03)$ canals, although there was no significant difference in the amount of leakage for $\mathrm{CW}$ and $\mathrm{ZC}(p>0.05)$. X-ray diffraction revealed the presence of tricalcium silicate $\left(\mathrm{Ca}_{3} \mathrm{SiO}_{5}\right)$ and calcium zirconate $\left(\mathrm{CaZrO}_{3}\right)$ in the synthesized $\mathrm{ZC}$. Scanning electron microscopy revealed mineralized precipitates on the dentin of canals obturated by $\mathrm{ZC}$. The novel calcium zirconate silicate cement appears to promote biomineralization and seal root canals at least as effectively as the conventional sealer.
\end{abstract}

Keywords: calcium silicate-based sealer; endotoxin leakage; scanning electron microscopy; sealing ability; calcium zirconate silicate cement

\section{Introduction}

Endodontic treatment needs to eliminate microbes and seal canals [1]. However, the commonly used gutta-percha (GP) cones with root canal sealers do not completely seal root canals [2]. Strategies 
for enhancing the seal include materials that adhere to dentin [3], self-sealing gaps by setting or hygroscopic expansion of the core material or sealer [4,5], enhancement of the flow and adaptation of fillings within root canal systems [6]. Recently, the materials that form a mineralized layer at the interface with root canal dentin have shown promise in sealing root canals. These include the calcium silicate-based sealers shown to stimulate hydroxyapatite nucleation and bio-mineralization within dentinal tubules, which have been examined in previous studies [7-9].

The calcium silicate-based products include Endosequence BC sealer ${ }^{\circledR}(\mathrm{EBC}$, Brasseler, Savannah, GA, USA), which contains $\mathrm{Ca}_{2} \mathrm{SiO}_{4}, \mathrm{Ca}\left(\mathrm{H}_{2} \mathrm{PO}_{4}\right)_{2}, \mathrm{ZrO}_{2}$ and $\mathrm{Ca}(\mathrm{OH})_{2}$ [10]. EBC's post-setting $\mathrm{pH}$ of over 10.5 provides antibacterial properties [11-13], it releases significantly more calcium ions than the epoxy resin sealer and it can form a hydroxyapatite layer at the interface with dentin [11]. A slight setting expansion $(0.087 \pm 0.04 \%)$ [12] further improves adaptation in the root canal.

Another calcium silicate filling material is mineral trioxide aggregate (MTA), which provides an excellent seal, is highly biocompatible and promotes biomineralization [14]. Mineralization within the dentinal tubules has been observed in root canals obturated with MTA in vitro [7,15]. However, the bismuth oxide $\left(\mathrm{Bi}_{2} \mathrm{O}_{3}\right)$ added for radiopacity can retard hydration, prolong the setting time, increase porosity, cause discoloration and may be cytotoxic to human periodontal ligament cells [16-19]. As substitutes, zirconium oxide $\left(\mathrm{ZrO}_{2}\right)$ had physicochemical properties that were comparable to MTA when $\mathrm{ZrO}_{2}$ was used with calcium silicate cement $[20,21]$. However, $\mathrm{ZrO}_{2}$ surfaces may contain heterogeneous nucleation sites for the precipitation and growth of early calcium silicate hydrate gel products [22]. MTA also contains tetracalcium aluminoferrite and some heavy metals in its composition $[23,24]$. Aluminum is toxic to osteoblasts and inhibits bone mineralization, while ferric ions can discolor teeth $[25,26]$. Therefore, a novel $\mathrm{CaZrO}_{3}$-containing calcium silicate cement $(\mathrm{ZC})$ composed of tricalcium silicate and calcium zirconate was created by a solid-state reaction to exclude $\mathrm{ZrO}_{2}$, aluminum and heavy metals.

The aim of this in vitro study was to evaluate the sealing ability of root canals that had been obturated with either the novel ZC, a single GP cone (SC) with EBC or the continuous wave of condensation (CW) using GP and epoxy resin sealer. The endotoxin leakage was measured in canals and biomineralization was identified at the interface with dentin.

\section{Results}

ZC was synthesized successfully by a solid-state reaction. Field emission scanning electron microscopic (FE-SEM, Model S 4700, Hitachi, Tokyo, Japan) examination of the synthesized cement powders revealed an irregular surface morphology and dimensions of $<5 \mu \mathrm{m}$. There were small particles $<1 \mu \mathrm{m}$ on the surface of tricalcium silicate (Figure 1A). X-ray diffraction (D8-Advance, Bruker AXS Inc., Madison, WI, USA) (Figure 1B) showed that the synthesized ZC was a mixture of tricalcium silicate $\left(\mathrm{Ca}_{3} \mathrm{SiO}_{5}\right.$, JCDPS \# 31-0301) and calcium zirconate $\left(\mathrm{CaZrO}_{3}, \mathrm{JCDPS}\right.$ \# 35-0790). There was no $\mathrm{Bi}_{2} \mathrm{O}_{3}$ or $\mathrm{ZrO}_{2}$, which are found in OrthoMTA (BioMTA, Seoul, Korea) and RetroMTA (BioMTA), respectively (Figure 1B). The scanning transmission electron microscopy (STEM, Model JEM-2100F, JEOL Ltd., Tokyo, Japan) image and energy dispersive spectroscopy (EDS) mappings showed that $\mathrm{Ca}$ and $\mathrm{Si}$ were uniformly distributed over the entire surface of tricalcium silicate and $\mathrm{Zr}$ was locally present (Figure 1C-F). Therefore, the small particles observed on the surface of tricalcium silicate are likely to be calcium zirconate $\left(\mathrm{CaZrO}_{3}\right)$.

ZC-filled root canals showed a delay in endotoxin leakage (Table 1). All negative control canals remained endotoxin-free for 21 days, while all positive controls leaked endotoxin within 3 days (Figure 2). Several SC canals (25\%) leaked in 3 days and most (67\%) leaked within 9 days. However, only one canal in each of CW and ZC leaked after 6 days. Eventually, most SC canals (75\%), half of CW $(50 \%)$ and less than half of ZC (42\%) leaked after 21 days. There were more SC canals than CW or ZC that leaked on the 3rd, 9th and 12th days. After 21 days, there was significantly more leaked endotoxin in the SC canals when compared to the leakage in the CW $(p=0.031)$ or ZC $(p=0.03)$ canals 
(Figure 2A). However, there was no significant $(p>0.05)$ difference in the amount of leaked endotoxin between the CW and ZC canals.

Table 1. The mean amount of endotoxin leakage $(\mathrm{EU} / \mathrm{mL})$ and ratio of the leaked specimens measured after 21 days of exposure for the experimental groups and control groups.

\begin{tabular}{cccccc}
\hline Group & NC & PC & CW & SC & ZC \\
\hline $\begin{array}{c}\text { Amount of leaked } \\
\text { endotoxin (Mean } \pm \text { SD) } \\
(\text { EU } / \mathrm{mL})\end{array}$ & $<0.01$ & $1.281 \pm 0.284$ & $0.324 \pm 0.235$ & $0.641 \pm 0.225$ & $0.303 \pm 0.091$ \\
\hline$(\%$ of PC) & & & & & \\
\hline $\begin{array}{c}\text { Number leaked/total } \\
(\%)\end{array}$ & $(<1 \%)$ & $(100 \%)$ & $(25 \%)$ & $(50 \%)$ & $(24 \%)$ \\
\hline
\end{tabular}

NC: negative control; PC: positive control; CW: continuous wave of condensation with GP and AH 26 sealer; SC: single GP cone obturation with EndoSequence BC sealer; $\mathrm{ZC}$ : obturation with $\mathrm{CaZrO}_{3}$-containing calcium silicate cement. * Percent ratio of the amount of leaked endotoxin relative to the amount of leaked endotoxin in PC.
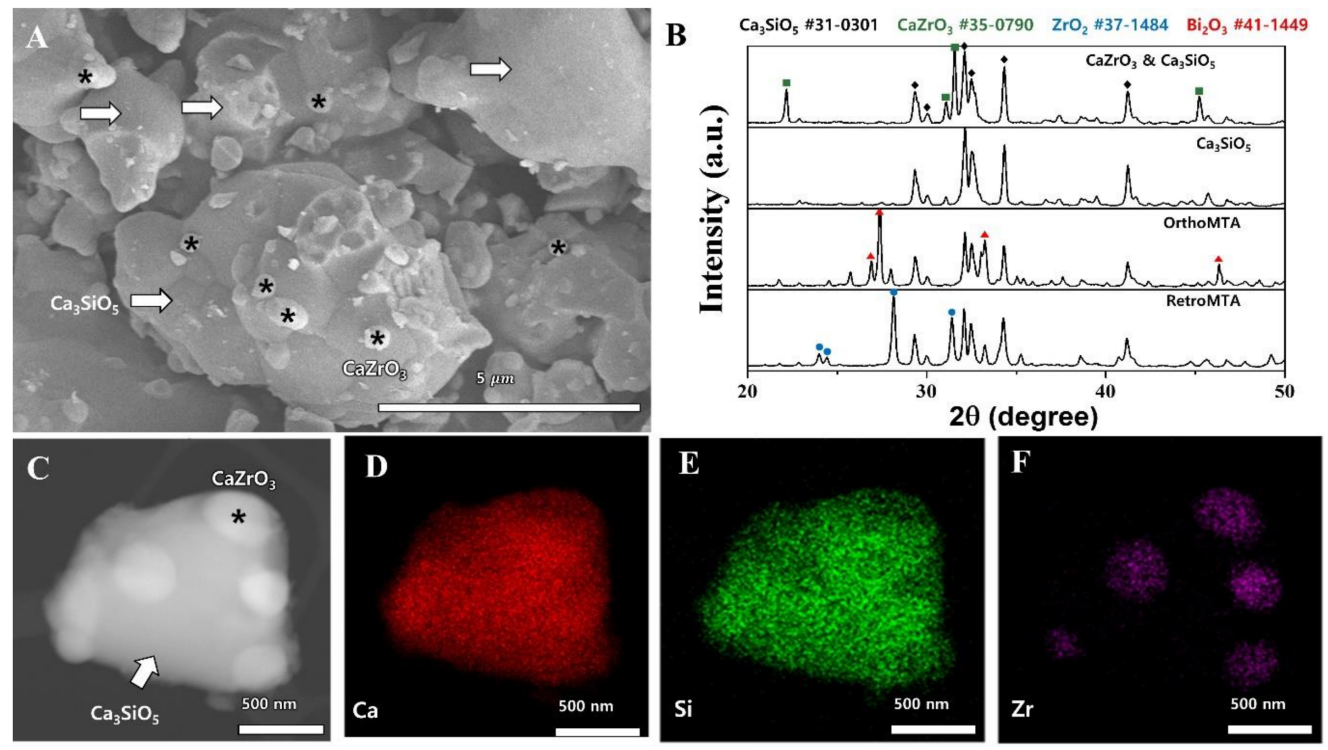

Figure 1. Phase analysis of $\mathrm{CaZrO}_{3}$-containing calcium silicate cement. (A) FE-SEM image of the synthesized $\mathrm{CaZrO}_{3}$-containing calcium silicate cement $(\times 10,000)$; calcium zirconate $\left({ }^{*}\right)$ was generated, scattered around the tricalcium silicate facet (arrows). (B) X-ray diffraction pattern of the synthesized cement, tricalcium silicate without $\mathrm{ZrO}_{2}$, OrthoMTA and RetroMTA. The elemental analysis showed the presence of tricalcium silicate $\left(\mathrm{Ca}_{3} \mathrm{SiO}_{5}\right)$ and calcium zirconate $\left(\mathrm{CaZrO}_{3}\right)$ in the synthesized cement. Bismuth oxide $\left(\mathrm{Bi}_{2} \mathrm{O}_{3}\right)$ and zirconium oxide $\left(\mathrm{ZrO}_{2}\right)$, which are components of OrthoMTA and RetroMTA, respectively, were not found in the synthesized cement. (C) STEM image of the synthesized cement; in which, calcium zirconate $\left(^{*}\right)$ and tricalcium silicate (arrow) were observed. (D-F) EDS mapping of the synthesized cement showed that $\mathrm{Zr}$ was locally present on the surface of tricalcium silicate and the small particles on the surface are calcium zirconate $\left(\mathrm{CaZrO}_{3}\right)$.

Biomineralization occurred in the ZC-filled dentinal tubules. The FE-SEM examination showed that CW canals had clear demarcations at the dentin-sealer interface (Figure 3(A1)) when the unsealed dentinal tubules (Figure 3(A2)) and the tubules covered with AH 26 sealer (Dentsply De Trey, Konstanz, Germany) were used (Figure 3(A3,4)). The SC canals showed partial separation of the EBC sealer from dentin and sealer impregnation of the dentinal tubules (Figure 3(B1,3,4)). The cross-sectional examination of ZC canals revealed dense fillings (Figure 3(C1)). ZC had penetrated into dentinal tubules and formed tag-like, rod-like and globular mineral structures (Figure 3(C3,4)). 
(A)

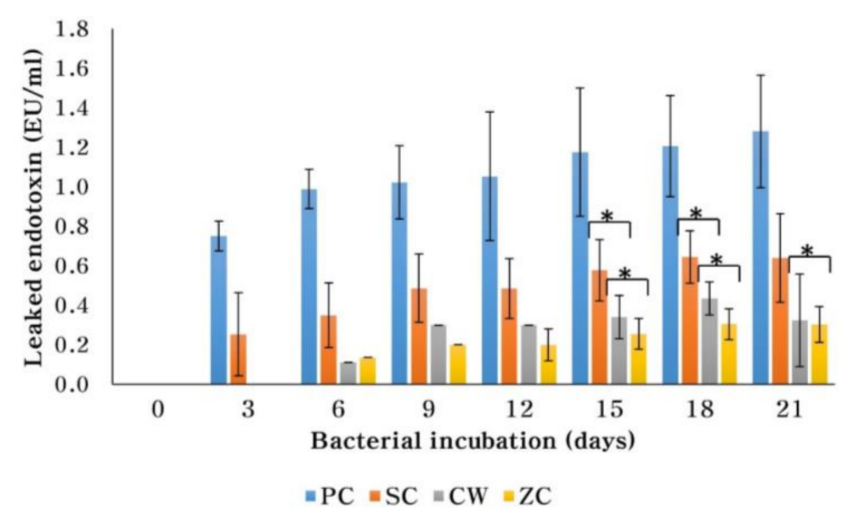

(B)

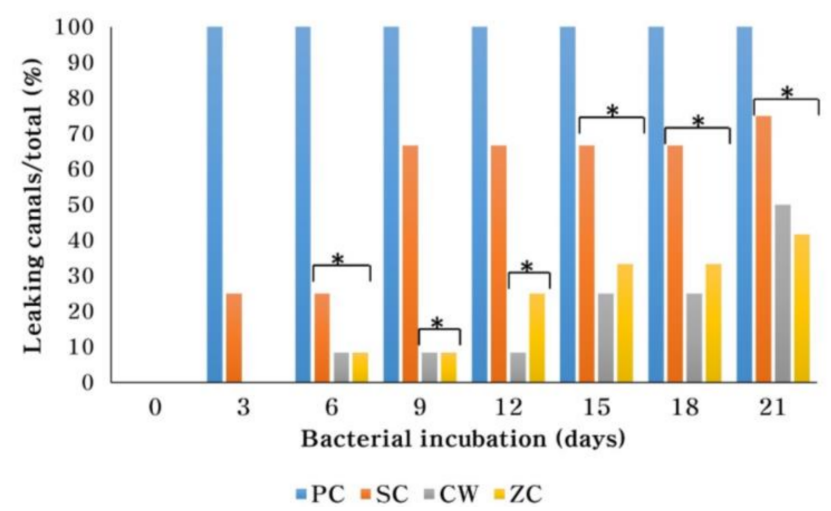

Figure 2. The amount (EU/mL) of endotoxin leakage (A) after 3, 6, 9, 12, 15, 18 and 21 days of bacterial incubation, and the ratio of root canals that leaked endotoxin (B). An asterisk $\left(^{*}\right)$ means no significant difference between groups. All negative control canals remained endotoxin-free for 21 days.

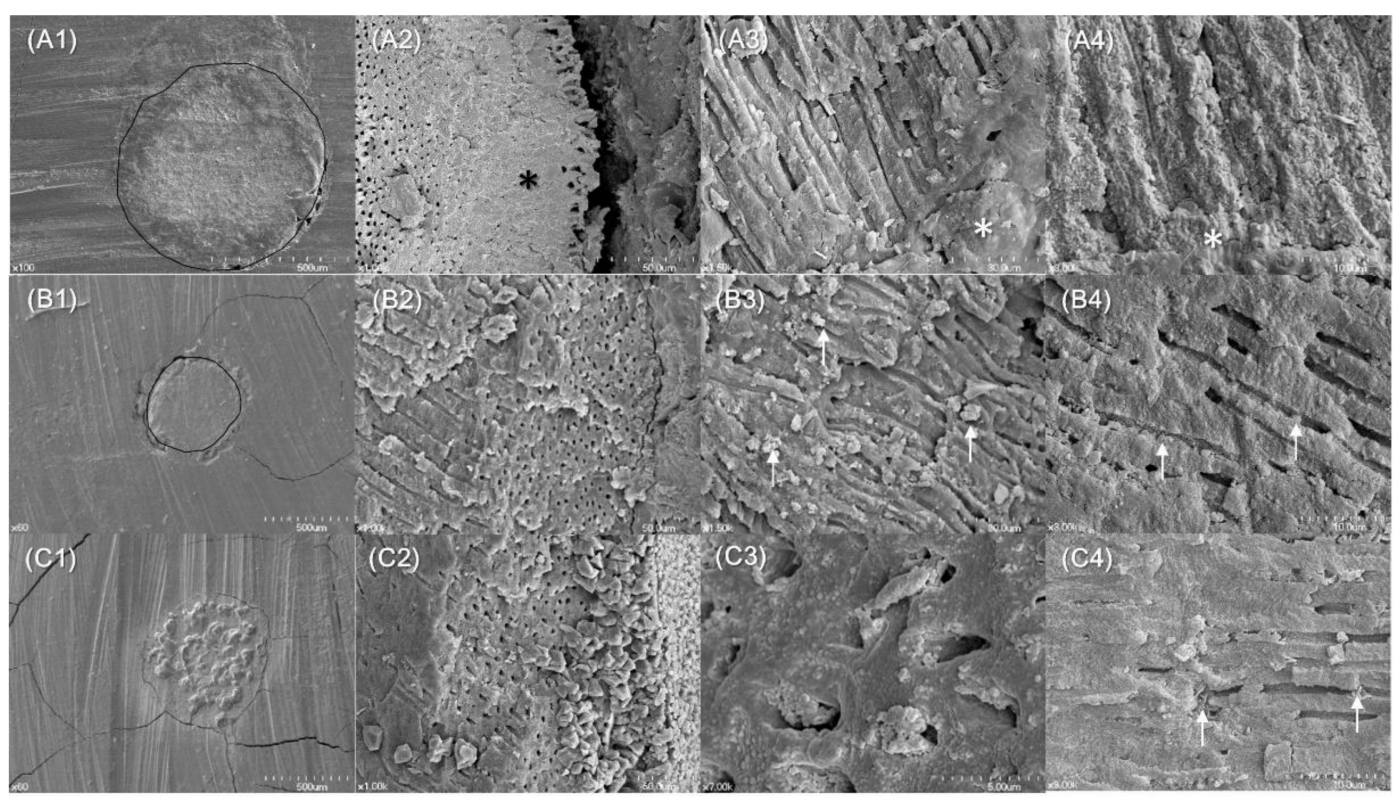

Figure 3. Scanning electron microscopic images of gutta-percha and AH 26 sealer (A), gutta-percha and EndoSequence $\mathrm{BC}$ sealer $(\mathbf{B})$ and $\mathrm{CaZrO}_{3}$-containing calcium silicate cements $(\mathbf{C})$ filled root canals of human premolars. 
(A1) $(\times 100)$ A cross-sectional view at $2 \mathrm{~mm}$ from the root tip with GP demarcated by a circle. (A2) $(\times 1000)$ Dentinal tubules on the root canal wall had some open orifices and other orifices that were partially blocked with the sealer (asterisk). $(\mathrm{A} 3)(\times 1500)$ Some of the dentin on the canal walls was covered with AH 26 sealer (asterisk). (A4) $(\times 3000)$ Orifices of dentinal tubules that were blocked with AH 26 sealer (asterisk).

(B1) $(\times 60)$ A cross-sectional view at $2 \mathrm{~mm}$ from the root tip with GP demarcated by a circle. Distinguishing the EBC sealer from dentin was difficult due to the impregnation of dentin with a sealer, which is seen in the lower part of this image. There was a gap at the interface of dentine and filling material in the left portion of this image. $(B 2)(\times 1000)$ There were dentinal tubules with open orifices on the canal walls. $(B 3)(\times 1500)$ and $(B 4)(\times 3000)$ Dentin on canal walls was partially occluded with EBC sealer (arrows).

(C1) $(\times 60)$ A cross-sectional view at $2 \mathrm{~mm}$ from the root tip, with the $\mathrm{CaZrO}_{3}$-containing calcium silicate cement shown to have densely filled the canal. $(\mathrm{C} 2)(\times 1000)$ Most of the dentinal tubules orifices on the canal wall were covered with cubic-shaped crystals. (C3) $(\times 7000)$ Tubule orifices were filled with tag-like structures that were partially fused with peritubular dentin. $(C 4)(\times 3000)$ There were rod-like mineralized structures (arrows) within the dentinal tubule.

\section{Discussion}

This study evaluated the sealing ability of different obturation materials and techniques by measuring endotoxin leakage with the LAL assay. The leakage models that use dyes, glucose, bacteria or radioisotopes may lack reproducibility, standardization and correlation between models [27]. Alternatively, the fluid filtration model is quantitative and allows repeated measurements, although only continuous coronal-apical voids are detectable [2]. The bacterial lipopolysaccharide is an endotoxin and is a general virulence factor present in the outer membrane of gram-negative bacteria that is predominantly involved in root canal infections [28]. The presence of endotoxin in infected root canals has a dose-dependent association with clinical and radiographic features of periapical disease [28,29]. Infected canals commonly contain Porphyromonas gingivalis (P. gingivalis), which were the bacteria used to measure leakage in this study [30]. Their endotoxin activates a proenzyme in the catalytic coagulation cascade of LAL in a dose-dependent manner and is thus measured in the LAL assay [31,32]. Additionally, limiting the assessment to straight mandibular premolars with single canals ensured better comparability [33].

The SC canals had more leakage than CW or ZC canals. SC canals required more sealer than the $\mathrm{CW}$ due to the size discrepancy between a single \#40/06 GP cone and the canal, which particularly occurs within the middle and coronal thirds [34]. The larger volume of sealer around a single GP failed to provide a tight seal. Without compaction, there is little adaptation of GP to anatomic variations within canals and thus, a large volume of sealer may be unevenly distributed upon injection and result in voids [35]. The subsequent dissolution of the sealer causes leakage. Indeed, the EBC sealer is more soluble than either the epoxy resin- or calcium hydroxide-based sealers [12], although their solubility $(2.9 \pm 0.5 \%)$ meets the American National Standards Institute/American Dental Association requirements $(<3 \%)$.

ZC canals were as resistant to endotoxin leakage as CW. ZC hydration products may have contributed to its sealing ability according to the following theory. $\mathrm{CaO}$ may have reacted with water to form $\mathrm{Ca}(\mathrm{OH})_{2}$, which subsequently dissociated into $\mathrm{Ca}^{2+}$ and $\mathrm{OH}^{-}[36] . \mathrm{Ca}^{2+}$ reacted with $\mathrm{CO}_{2}$ in tissues to form $\mathrm{CaCO}_{3}$ [36], which reduced gaps and increased retention [6]. Another hydration product that may have contributed to the seal is calcium silicate hydrate gel [37]. The gel forms tag-like structures in dentinal tubules and reacts with $\mathrm{PO}_{4}{ }^{2-}$ in dentinal fluid to form hydroxyapatite crystals that gradually occlude the tubules [15].

None of the obturating materials or techniques tested could completely seal canals. ZC microleakage may have increased the porosity of the cement [38]. Hydrated ZC has been shown to have porosities and microchannels due to insufficient packing, inadequate water/powder ratio or evaporation $[17,38,39]$. 
For calcium silicate cements, micro-CT (computed tomography) studies showed voids within the filling material and against the canal wall [39,40]. CW canal leakage was consistent with prior studies [34,41] and may have originated from inadequate bonding between the epoxy resin sealer and GP or dentin $[2,6]$. Some SC canals leaked as early as 3 days and many more leaked within 9 days before plateauing as the setting expansion of the EBC sealer reduced leakage [42]. Its setting was probably delayed in the humidifier, since prior studies found greater water absorption of calcium silicate cement [43] and faster settings when immersed in water [12,42,44].

There were differences in the sealer occlusion of dentinal tubules on the canal walls. In the $\mathrm{CW}$ canals, the AH 26 epoxy resin sealer formed a physical barrier without integrating with dentin (Figure 3(A3,4)). In contrast, the SC (EBC) and ZC canals showed actual penetration of dentinal tubules (Figure 3(B3,4) and Figure 3(C3,4)). Similarly, previous studies observed biomineralization by the calcium silicate cement at the cement-dentin interface [7,15]. However, in the current study, EBC composed of tricalcium silicate and calcium phosphate hybrids failed to form mineralized precipitates (Figure 3B), since calcium hydroxide was not produced by its hydration [23]. In contrast, ZC canals contained the cement and hydration products within their dentinal tubules. These hydration products were rod-like elongated structures (Figure $3(C 3,4)$ ) that could have blocked endotoxin penetration. However, despite differences in the penetration depth of obturating materials in the CW and ZC canals, their mean amounts of leaked endotoxin were comparable. Similarly, a previous study reported a lack of correlation between sealer penetration into dentinal tubules and the sealing ability of the sealer [45]. Since the endotoxin leakage model and micro-CT assessment are non-destructive assessment methods, further micro-CT evaluation of the tested specimens would be valuable $[39,40]$.

Similarly, other studies have attested to the benefits of the calcium silicate cements with zirconium [20,21]. Calcium silicate cement with $\mathrm{ZrO}_{2}$ had more compressive strength and resulted in less inflammation in rat tissues than those with $\mathrm{Bi}_{2} \mathrm{O}_{3}$ [21]. Calcium silicate cement with $30 \% \mathrm{ZrO}_{2}$ had setting times, an alkaline $\mathrm{pH}$ and calcium release that was similar to MTA [20]. However, since $\mathrm{ZrO}_{2}$ could hinder cement hydration with a heterogeneous phase [22], ZC was synthesized with calcium zirconate and tricalcium silicate (for radiopacity) to exclude the $\mathrm{ZrO}_{2}$ isolated previously. This synthesized calcium zirconate was scattered around tricalcium silicate particles (Figure 1). Canals filled with the novel ZC and canals obturated by CW resisted endotoxin leakage. Therefore, additional studies examining the push-out bond strength, flow, radiopacity, dimensional stability and a molecular analysis of the ZC hydration products are warranted.

\section{Materials and Methods}

\subsection{Synthesis and Morphology Analysis of Calcium Zirconate Containing Calcium Silicate}

$\mathrm{ZC}$ was synthesized by a solid-state reaction using $\mathrm{SiO}_{2}, \mathrm{CaO}$ and $\mathrm{ZrO}_{2}$. The morphology of the synthesized powder was observed by FE-SEM (Model S4700) and STEM (Model JEM-2100F) equipped with EDS. The phase was examined by X-ray diffraction (Model D8-Advance) and compared with that of the synthesized tricalcium silicate cement without $\mathrm{ZrO}_{2}$, RetroMTA (BioMTA), and OrthoMTA (BioMTA).

\subsection{Root Canal Preparation}

Study approval was obtained from the Institutional Review Board at Seoul National University Dental Hospital, Seoul, Republic of Korea (ERI 16003). Extracted human mandibular premolars $(N=57)$ with straight single canals without previous root canal treatment, fractures below the cemento-enamel junction, root caries, root resorption or open apices were used. Periapical radiography was taken at the buccolingual and mesiodistal views to confirm a straight single root canal. After extraction, soft-tissue remnants were removed from teeth with thymol-soaked gauze. After this, the teeth were stored in $0.1 \%$ thymol at $25{ }^{\circ} \mathrm{C}$ for less than six months. Crowns were removed with a high-speed diamond (TR-13, Mani, Tochigi, Japan) and root lengths were standardized (12 $\pm 0.5 \mathrm{~mm})$. The working length 
was established to be $1 \mathrm{~mm}$ from the apex, while canals were enlarged with ProTaper Next (Dentsply Maillefer, Ballaigues, Switzerland) up to X4 (\#40/06). They were irrigated with $2 \mathrm{~mL}$ of $3.5 \% \mathrm{NaOCl}$ between instruments, before being rinsed with $5 \mathrm{~mL}$ of $17 \%$ EDTA followed by $10 \mathrm{~mL}$ of $3.5 \% \mathrm{NaOCl}$ to remove smear layer. Finally, they were flushed with $10 \mathrm{~mL}$ of saline to remove any remaining irrigant, before drying with paper points. The roots were randomly divided into three experimental (15 roots per group) and two control groups (6 roots per group). All canals were prepared and obturated by one endodontist.

\subsection{Obturations}

CW $(N=15)$ : Root canals were obturated by the continuous wave of condensation technique using a \#40/06 GP cone (Diadent, Chung-ju, Korea) and epoxy resin sealer (AH 26). Sealer was first coated onto GP and applied to the canal by a pumping motion. A B\&L alpha II tip (B\&L Biotech, Ansan, Korea) was activated and heated to $200{ }^{\circ} \mathrm{C}$ as it was inserted into the GP cone in the canal with light apical pressure until it reached a point that was 4-5 $\mathrm{mm}$ from the apical foramen. After this, the tip was deactivated for about $8 \mathrm{~s}$ and again reactivated to remove the coronal portion of the master cone. The gutta-percha that remained within the apical portion was immediately compacted with a BL S-Kondenser (B\&L Biotech). Finally, the coronal portion of the canal was obturated with thermo-plasticized gutta-percha (B\&L-beta; B\&L Biotech), before being vertically condensed with BL S-Kondenser.

SC $(N=15)$ : Root canals were obturated by a single cone technique using a \#40/06 GP cone and EBC sealer ${ }^{\circledR}$. EBC sealer was first dispensed into the canal through its syringe tip and a GP cone was inserted to the working length, according to the manufacturer's instructions. A B\&L alpha II tip was placed at the orifice of the canal, which was then activated and moved laterally without apical pressure to remove excess GP.

ZC $(N=15)$ : Canals were obturated with ZC as previously described [15]. ZC powder was mixed into paste with distilled water and dispensed into the canal by OrthoMTA carrier (BioMTA). After this, the powder was plugged and spread using an OrthoMTA compactor file (BioMTA). The remaining canal was repeatedly filled with the ZC paste using BL-S Kondensers (B\&L Biotech). Root canal obturating materials used in the present study are described in Table 1.

PC $(N=6)$ : As positive controls, canals were obturated with GP without a sealer.

NC $(N=6)$ : As negative controls, unfilled canals had the entire root surface covered with nail varnish and sticky wax.

After obturation, all specimens were stored at $37{ }^{\circ} \mathrm{C}$ and $100 \%$ humidity for 1 week to ensure complete setting of the materials. A pilot study had revealed that $\mathrm{ZC}$ requires moisture and takes about 90 min to adequately set. After this, all root surfaces (except NC) were covered with nail varnish and sticky wax, leaving only the canal orifice and the apical $1 \mathrm{~mm}$ of the root exposed.

\subsection{Endotoxin Leakage}

Leakage was measured through a dual chamber model as previously described [41,46]. The obturated (12/group) and control (6/group) roots were inserted into plastic 2-mL Eppendorf tubes with their tapered base removed. The gaps between the tube and root were sealed with acrylic resin and cyanoacrylate glue. All specimens were sterilized with ethylene oxide at $56{ }^{\circ} \mathrm{C}$ for four hours. Each root tip was submerged in $3 \mathrm{~mL}$ of Hank's Balanced Salt Solution in a sterile flask, which was then sealed with acrylic resin and cyanoacrylate glue. One-mL aliquots of $P$. gingivalis were placed on the coronal root at the Eppendorf tube entrance, which were then incubated in an anaerobic chamber at $37^{\circ} \mathrm{C}$ for 21 days. Fresh bacterial suspensions were added every three days. The lower chamber of the sterile flask was sampled every third day for 21 days. The $P$. gingivalis endotoxin was measured using the LAL assay (Lonza, Walkersville, MD, USA). 


\subsection{Statistical Analysis}

Leaked endotoxin concentrations and ratios of leaked specimens were analyzed by one-way ANOVA with Scheffe's test $(\alpha=0.05)$ using SPSS statistics version 20 (IBM, Armonk, NY, USA).

\subsection{Biomineralization Identified}

Ultrastructural features were examined by FE-SEM (CW/SC/ZC, $n=3$ /group). These obturated roots were stored in an incubator with $100 \%$ humidity at $37^{\circ} \mathrm{C}$ for 21 days, before being cross-sectioned at $2 \mathrm{~mm}$ from the root tip with a low speed diamond disk (Kerr, Orange, CA, USA). The coronal segments were split longitudinally through the center by creating longitudinal grooves on their outer surfaces with a low-speed diamond disk, before applying a blade and hammer. These cross-sections and segments were mounted on aluminum stubs and sputter-coated with a 30-nm layer of gold. The cross-sectional surfaces and filling-dentin interface were examined by FE-SEM (Model S 4700) at $\times 60,100,1000,1500,3000$ and 7000 magnifications.

\section{Conclusions}

Canals filled with a novel $\mathrm{CaZrO}_{3}$-containing calcium silicate cement alone were as resistant to endotoxin leakage as those obturated by CW with GP and AH 26 sealer; and much more resistant than a single cone obturation with GP and EBC sealer. Canals sealed with this ZC cement had mineralization within dentinal tubules over 21 days. The novel $\mathrm{CaZrO}_{3}$-containing calcium silicate cement may be suitable to be used as a canal obturating material.

Acknowledgments: This research was supported by an Engineering-Dentistry Interdisciplinary Research Grant, jointly funded by the College of Engineering and the School of Dentistry, Seoul National University, Seoul, Republic of Korea (860-20150009).

Author Contributions: Seong-Hyeon Hong, Won-Jun Shon, Seung-Ho Baek, Seok Woo Chang, and Kee-Yeon Kum conceived and designed the experiments; Soram Oh, Sung-In Cho, and Jinsu You performed the experiments; Soram Oh, Sung-In Cho, Yeon-Jee Yoo, Seok Woo Chang, and Jun-Sang Yoo analyzed the data; Soram Oh, Sung-In Cho, Hiran Perinpanayagam, Jinsu You, and Kee-Yeon Kum wrote the manuscript. Both Soram Oh and Sung-In Cho contributed to this study as first authors.

Conflicts of Interest: The authors declare no conflicts of interest.

\section{References}

1. Figdor, D.; Sundqvist, G. A big role for the very small-Understanding the endodontic microbial flora. Aust. Dent. J. 2007, 52, S38-S51. [CrossRef] [PubMed]

2. Bouillaguet, S.; Shaw, L.; Barthelemy, J.; Krejci, I.; Wataha, J.C. Long-term sealing ability of pulp canal sealer, AH-plus, guttaflow and epiphany. Int. Endod. J. 2008, 41, 219-226. [CrossRef] [PubMed]

3. Schwartz, R.S. Adhesive dentistry and endodontics. Part 2: Bonding in the root canal system-the promise and the problems: A review. J. Endod. 2006, 32, 1125-1134. [CrossRef] [PubMed]

4. Hammad, M.; Qualtrough, A.; Silikas, N. Extended setting shrinkage behavior of endodontic sealers. J. Endod. 2008, 34, 90-93. [CrossRef] [PubMed]

5. $\quad$ Eid, A.A.; Nikonov, S.Y.; Looney, S.W.; Didato, A.; Niu, L.N.; Levin, M.D.; Rueggeberg, F.A.; Pashley, D.H.; Watanabe, I.; Tay, F.R. In vitro biocompatibility evaluation of a root canal filling material that expands on water sorption. J. Endod. 2013, 39, 883-888. [CrossRef] [PubMed]

6. Li, G.H.; Niu, L.N.; Zhang, W.; Olsen, M.; De-Deus, G.; Eid, A.A.; Chen, J.H.; Pashley, D.H.; Tay, F.R. Ability of new obturation materials to improve the seal of the root canal system: A review. Acta Biomater. 2014, 10, 1050-1063. [CrossRef] [PubMed]

7. Yoo, Y.J.; Baek, S.H.; Kum, K.Y.; Shon, W.J.; Woo, K.M.; Lee, W. Dynamic intratubular biomineralization following root canal obturation with pozzolan-based mineral trioxide aggregate sealer cement. Scanning 2016, 38, 50-56. [CrossRef] [PubMed] 
8. Salles, L.P.; Gomes-Cornelio, A.L.; Guimaraes, F.C.; Herrera, B.S.; Bao, S.N.; Rossa-Junior, C.; Guerreiro-Tanomaru, J.M.; Tanomaru-Filho, M. Mineral trioxide aggregate-based endodontic sealer stimulates hydroxyapatite nucleation in human osteoblast-like cell culture. J. Endod. 2012, 38, 971-976. [CrossRef] [PubMed]

9. Weller, R.N.; Tay, K.C.; Garrett, L.V.; Mai, S.; Primus, C.M.; Gutmann, J.L.; Pashley, D.H.; Tay, F.R. Microscopic appearance and apical seal of root canals filled with gutta-percha and proroot endo sealer after immersion in a phosphate-containing fluid. Int. Endod. J. 2008, 41, 977-986. [CrossRef] [PubMed]

10. Jafari, F.; Jafari, S. Composition and physicochemical properties of calcium silicate based sealers: A review article. J. Clin. Exp. Dent. 2017, 9, e1249-e1255. [CrossRef] [PubMed]

11. Candeiro, G.T.; Correia, F.C.; Duarte, M.A.; Ribeiro-Siqueira, D.C.; Gavini, G. Evaluation of radiopacity, pH, release of calcium ions, and flow of a bioceramic root canal sealer. J. Endod. 2012, 38, 842-845. [CrossRef] [PubMed]

12. Zhou, H.M.; Shen, Y.; Zheng, W.; Li, L.; Zheng, Y.F.; Haapasalo, M. Physical properties of 5 root canal sealers. J. Endod. 2013, 39, 1281-1286. [CrossRef] [PubMed]

13. Singh, G.; Gupta, I.; Elshamy, F.M.; Boreak, N.; Homeida, H.E. In vitro comparison of antibacterial properties of bioceramic-based sealer, resin-based sealer and zinc oxide eugenol based sealer and two mineral trioxide aggregates. Eur. J. Dent. 2016, 10, 366-369. [CrossRef] [PubMed]

14. Torabinejad, M.; Parirokh, M. Mineral trioxide aggregate: A comprehensive literature review-Part ii: Leakage and biocompatibility investigations. J. Endod. 2010, 36, 190-202. [CrossRef] [PubMed]

15. Yoo, J.S.; Chang, S.W.; Oh, S.R.; Perinpanayagam, H.; Lim, S.M.; Yoo, Y.J.; Oh, Y.R.; Woo, S.B.; Han, S.H.; Zhu, Q.; et al. Bacterial entombment by intratubular mineralization following orthograde mineral trioxide aggregate obturation: A scanning electron microscopy study. Int. J. Oral Sci. 2014, 6, 227-232. [CrossRef] [PubMed]

16. Coomaraswamy, K.S.; Lumley, P.J.; Hofmann, M.P. Effect of bismuth oxide radioopacifier content on the material properties of an endodontic portland cement-based (MTA-like) system. J. Endod. 2007, 33, $295-298$. [CrossRef] [PubMed]

17. Grazziotin-Soares, R.; Nekoofar, M.H.; Davies, T.E.; Bafail, A.; Alhaddar, E.; Hubler, R.; Busato, A.L.; Dummer, P.M. Effect of bismuth oxide on white mineral trioxide aggregate: Chemical characterization and physical properties. Int. Endod. J. 2014, 47, 520-533. [CrossRef] [PubMed]

18. Kim, E.C.; Lee, B.C.; Chang, H.S.; Lee, W.; Hong, C.U.; Min, K.S. Evaluation of the radiopacity and cytotoxicity of portland cements containing bismuth oxide. Oral Surg. Oral Med. Oral Pathol. Oral Radiol. Endod. 2008, 105, e54-e57. [CrossRef] [PubMed]

19. Marciano, M.A.; Costa, R.M.; Camilleri, J.; Mondelli, R.F.; Guimaraes, B.M.; Duarte, M.A. Assessment of color stability of white mineral trioxide aggregate angelus and bismuth oxide in contact with tooth structure. J. Endod. 2014, 40, 1235-1240. [CrossRef] [PubMed]

20. Bosso-Martelo, R.; Guerreiro-Tanomaru, J.M.; Viapiana, R.; Berbert, F.L.; Duarte, M.A.; Tanomaru-Filho, M. Physicochemical properties of calcium silicate cements associated with microparticulate and nanoparticulate radiopacifiers. Clin. Oral Investig. 2016, 20, 83-90. [CrossRef] [PubMed]

21. Silva, G.F.; Bosso, R.; Ferino, R.V.; Tanomaru-Filho, M.; Bernardi, M.I.; Guerreiro-Tanomaru, J.M.; Cerri, P.S. Microparticulated and nanoparticulated zirconium oxide added to calcium silicate cement: Evaluation of physicochemical and biological properties. J. Biomed. Mater. Res. A 2014, 102, 4336-4345. [CrossRef] [PubMed]

22. Coleman, N.J.; Li, Q. The impact of zirconium oxide radiopacifier on the early hydration behaviour of white portland cement. Mater. Sci. Eng. C Mater. Biol. Appl. 2013, 33, 427-433. [CrossRef] [PubMed]

23. Camilleri, J. Mineral trioxide aggregate: Present and future developments. Endod. Top. 2015, 32, 31-46. [CrossRef]

24. Kum, K.Y.; Zhu, Q.; Safavi, K.; Gu, Y.; Bae, K.S.; Chang, S.W. Analysis of six heavy metals in ortho mineral trioxide aggregate and proroot mineral trioxide aggregate by inductively coupled plasma-optical emission spectrometry. Austral. Endod. J. 2013, 39, 126-130. [CrossRef] [PubMed]

25. Rodriguez, M.; Felsenfeld, A.J.; Llach, F. Aluminum administration in the rat separately affects the osteoblast and bone mineralization. J. Bone Miner. Res. 1990, 5, 59-67. [CrossRef] [PubMed] 
26. Kohli, M.R.; Yamaguchi, M.; Setzer, F.C.; Karabucak, B. Spectrophotometric analysis of coronal tooth discoloration induced by various bioceramic cements and other endodontic materials. J. Endod. 2015, 41, 1862-1866. [CrossRef] [PubMed]

27. Wu, M.K.; Wesselink, P.R. Endodontic leakage studies reconsidered. Part i. Methodology, application and relevance. Int. Endod. J. 1993, 26, 37-43. [CrossRef] [PubMed]

28. Jacinto, R.C.; Gomes, B.P.; Shah, H.N.; Ferraz, C.C.; Zaia, A.A.; Souza-Filho, F.J. Quantification of endotoxins in necrotic root canals from symptomatic and asymptomatic teeth. J. Med. Microbiol. 2005, 54, 777-783. [CrossRef] [PubMed]

29. Cardoso, F.G.; Ferreira, N.S.; Martinho, F.C.; Nascimento, G.G.; Manhaes, L.R.; Rocco, M.A.; Carvalho, C.A.; Valera, M.C. Correlation between volume of apical periodontitis determined by cone-beam computed tomography analysis and endotoxin levels found in primary root canal infection. J. Endod. 2015, 41, 1015-1019. [CrossRef] [PubMed]

30. Stojanovic, N.; Krunic, J.; Popovic, B.; Stojicic, S.; Zivkovic, S. Prevalence of enterococcus faecalis and porphyromonas gingivalis in infected root canals and their susceptibility to endodontic treatment procedures: A molecular study. Srp. Arh. Celok. Lek. 2014, 142, 535-541. [CrossRef] [PubMed]

31. Ding, J.L.; Ho, B. Endotoxin detection-From limulus amebocyte lysate to recombinant factor C. Subcell. Biochem. 2010, 53, 187-208. [PubMed]

32. Marinho, A.C.; Polay, A.R.; Gomes, B.P. Accuracy of turbidimetric limulus amebocyte lysate assay for the recovery of endotoxin interacted with commonly used antimicrobial agents of endodontic therapy. J. Endod. 2015, 41, 1653-1659. [CrossRef] [PubMed]

33. De-Deus, G. Research that matters-Root canal filling and leakage studies. Int. Endod. J. 2012, 45, $1063-1064$. [CrossRef] [PubMed]

34. Monticelli, F.; Sadek, F.T.; Schuster, G.S.; Volkmann, K.R.; Looney, S.W.; Ferrari, M.; Toledano, M.; Pashley, D.H.; Tay, F.R. Efficacy of two contemporary single-cone filling techniques in preventing bacterial leakage. J. Endod. 2007, 33, 310-313. [CrossRef] [PubMed]

35. Celikten, B.; Uzuntas, C.F.; Orhan, A.I.; Orhan, K.; Tufenkci, P.; Kursun, S.; Demiralp, K.O. Evaluation of root canal sealer filling quality using a single-cone technique in oval shaped canals: An in vitro micro-CT study. Scanning 2016, 38, 133-140. [CrossRef] [PubMed]

36. Holland, R.; de Souza, V.; Nery, M.J.; Otoboni Filho, J.A.; Bernabe, P.F.; Dezan Junior, E. Reaction of rat connective tissue to implanted dentin tubes filled with mineral trioxide aggregate or calcium hydroxide. J. Endod. 1999, 25, 161-166. [CrossRef]

37. Gandolfi, M.G.; Prati, C. MTA and F-doped MTA cements used as sealers with warm gutta-percha. Long-term study of sealing ability. Int. Endod. J. 2010, 43, 889-901. [CrossRef] [PubMed]

38. Fridland, M.; Rosado, R. Mineral trioxide aggregate (MTA) solubility and porosity with different water-to-powder ratios. J. Endod. 2003, 29, 814-817. [CrossRef] [PubMed]

39. Jho, W.; Park, J.W.; Kim, E.; Song, M.; Seo, D.G.; Yang, D.K.; Shin, S.J. Comparison of root canal filling quality by mineral trioxide aggregate and gutta percha cones/ah plus sealer. Dent. Mater. J. 2016, 35, 644-650. [CrossRef] [PubMed]

40. Kim, S.; Kim, S.; Park, J.W.; Jung, I.Y.; Shin, S.J. Comparison of the percentage of voids in the canal filling of a calcium silicate-based sealer and gutta percha cones using two obturation techniques. Materials 2017, 10, 1170. [CrossRef] [PubMed]

41. Hwang, J.H.; Chung, J.; Na, H.S.; Park, E.; Kwak, S.; Kim, H.C. Comparison of bacterial leakage resistance of various root canal filling materials and methods: Confocal laser-scanning microscope study. Scanning 2015, 37, 422-428. [CrossRef] [PubMed]

42. Xuereb, M.; Vella, P.; Damidot, D.; Sammut, C.V.; Camilleri, J. In situ assessment of the setting of tricalcium silicate-based sealers using a dentin pressure model. J. Endod. 2015, 41, 111-124. [CrossRef] [PubMed]

43. Camilleri, J. Evaluation of the effect of intrinsic material properties and ambient conditions on the dimensional stability of white mineral trioxide aggregate and portland cement. J. Endod. 2011, 37, 239-245. [CrossRef] [PubMed]

44. Loushine, B.A.; Bryan, T.E.; Looney, S.W.; Gillen, B.M.; Loushine, R.J.; Weller, R.N.; Pashley, D.H.; Tay, F.R. Setting properties and cytotoxicity evaluation of a premixed bioceramic root canal sealer. J. Endod. 2011, 37, 673-677. [CrossRef] [PubMed] 
45. De-Deus, G.; Brandao, M.C.; Leal, F.; Reis, C.; Souza, E.M.; Luna, A.S.; Paciornik, S.; Fidel, S. Lack of correlation between sealer penetration into dentinal tubules and sealability in nonbonded root fillings. Int. Endod. J. 2012, 45, 642-651. [CrossRef] [PubMed]

46. Timpawat, S.; Amornchat, C.; Trisuwan, W.R. Bacterial coronal leakage after obturation with three root canal sealers. J. Endod. 2001, 27, 36-39. [CrossRef] [PubMed] article distributed under the terms and conditions of the Creative Commons Attribution (CC BY) license (http://creativecommons.org/licenses/by/4.0/). 